\title{
Ayurvedic Shodhana Treatments and Their Applied Aspect with Special Reference to Loha
}

\author{
Raman S. Belge ${ }^{1 *}$, Archana R. Belge ${ }^{2}$ \\ ${ }^{I}$ Dept. of Rasashastra \& Bhaishajya Kalpana, Shri Saptshrungi Ayurved College, Nashik, Maharashtra, India. \\ ${ }^{2}$ Dept. of Swasthavritta, Shri Saptshrungi Ayurved College, Nashik, Maharashtra, India.
}

\begin{abstract}
Shodhana (Purification) is the essential step to be performed on substances especially related to Rasashastra .Marana (Incineration of minerals) is always preceded by shodhana treatment. In short, shodhana treatment means; to remove unwanted part of the drug; to control/ eradicate toxic ingredients, to potentiate the drug, to regulate the action of the drug. The present paper gives the details of different Shodhana treatments and their applied aspect with special reference to Loha.
\end{abstract}

Keywords : Shodhana, Purification, Loha.

\section{Introduction:}

The ancient Ayurvedic Texts like Caraka Samhita have defined the concept of Shodhana. It Says that Karana (Processing) is the refinement of the natural products which means imparting other properties. These properties are infused by eight ways, one of them is Sauca (Cleansing) ${ }^{1}$

The concept of Shodhana treatment was highly accepted by the Pioneers of Rasashastra $\left(8^{\text {th }}\right.$ Century A.D.) especially for the Purification of Herbomineral drugs. The purification treatments were basically meant to reduce the toxicity level to a body-sustainable limit.

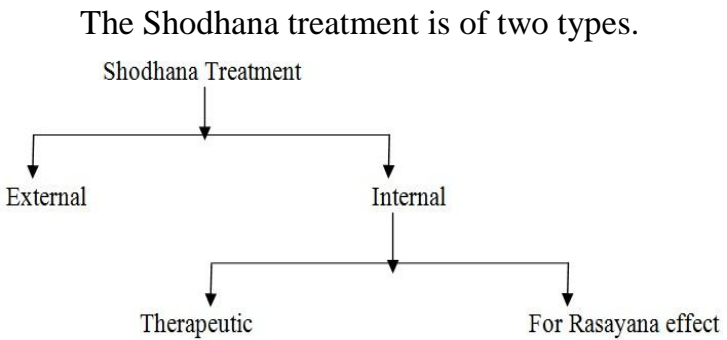

During Shodhana treatments the mineral drug undergoes various processes like cleaning, sifting, distillation, sorting, dehydration, filtering, peeling, polishing, straining, de-husking, washing etc. ${ }^{2}$

These Shodhana treatments ultimately result into following desired effects. (eg)

de- adulteration (eg. Pippali)

de-hydration (eg. Alum, Borax)

de-husking (eg. Jayapal, Dhatturaseeds)

de-toxification (eg. Gunja, Jayapal, Dhattura)

layer-separation (eg. Abharaka)

to make brittle (eg.Hiraka)

to reduce undesired effect like constipation (eg. Abhraka, Mandoor, Loha, Suvarna Makshika)

to reduce undesired effect like abdominal spasm (eg.Jayapala)

to reduce cardiotoxic effect (eg.Vatsanabha)

The Shodhana treatments include medium of acidic nature (eg.Lemon, Butter-milk, Kanji), alkaline nature (eg.Curnodaka) and of neutral nature (eg.water). These treatments are performed with or without the help of heat given for a specified time. Many a times the heating treatment is followed by dipping into cold fluids (eg.curnodaka, decoction, milk etc). This makes the mineral brittle, reduces particle size and thus exposes maximum drug to the purifying medium. These treatments loosen/wash/evaporate the toxic ingredients into the liquid medium and thus minerals become less toxic.

The Shodhana treatment is not only a method which takes away the physical \& chemical impurities from the mineral but also it potentiates the mineral by adding useful ingredient into it. In fact Ayurvedic Shodhana treatment is incorporation of organic substances (Herbs or drugs of animal origin) into inorganic substances. This incorporation not only helps in the faster absorption into body fluids but also makes it suitable for further process of Marana, Amrutikarana, Lohitikarana \& Satvapatana. The Present paper discusses the Ayurvedic Shodhana treatments and their applied aspect with special reference to Loha. 


\section{Literary Review:}

The Ancient Ayurvedic texts have described a therapeutic use of a few poisonous drugs ${ }^{3}$. However, these texts have no much details regarding purification of such poisonous and less poisonous drugs. It was only after $8^{\text {th }}$ Century A.D., when Rasashastra was studied and practiced the Shodhana Treatments gained importance. Since these drugs were highly efficient even with the little quantity ${ }^{4}$ they were accepted by the Vaidyas. The only disadvantage was their higher toxicity level with side effects which may even lead to death. It was observed that if this toxicity level could be minimized, the proper usage will make the drug a boon for the Vaidyas. ${ }^{5}$. Hence, Shodhana treatments were derived by the Rasashastra. These treatments turn the poisonous drug into non-toxic or less-toxic drug with minimum side effects. The aim of these treatments was to attain a toxicity level which is suitable to a normal person.

Rasashastra (Ancient Pharmaceutical Science) has described different drug-purification treatments. These treatments are aimed at reduction of toxins to make the drug patient-friendly or to make it suitable for further treatment like marana.

\section{Shodhana Treatments:}

\section{1) Nirvapana (Heating and dipping into liquid medium)}

The material taken for shodhana treatment is heated until it becomes red hot and immediately dipped into liquid medium eg.acidic (decoction of Triphala), alkaline(lime-water), Oils(sesame oil), milk etc.

The heating and dipping treatment is repeated until the material becomes brittle.

The hard materials line Abhraka (mica), Makshika, Loha, Mandoora, Tamra, Hiraka are purified by Nirwapana treatment.

This treatment results into particle disintegration the reduced particle size exposes more surface of the drug to an acidic/alkaline/oil medium.

The repeatition of Nirwapana is decided by judging the hardness of the mineral (Metals or Gems).

The knowledge of melting point and boiling point of the minerals must be considered before performing Shodhana treatment

The commenly used liquid media are Sesame oil, Butter-milk, Cows urine, Kanji(Sour gruel) and Kulattha-Kwatha.

\section{2) Dhalana (Heating, melting and dipping into liquid medium)}

The material taken for shodhana treatment is heated until it melts and then immediately poured into the cold liquid medium.

The treatment is repeated until the material becomes coarsely powdered and brittle.

The metals like Naga (Lead), Vanga (Tin) and Yashada (Zine), Gandhaka(Sulphur) are purified with this shodhana treatment

Churbidaka (lime-water) is the common medium used for Lead, Tin and Yashada Shodhana.

Sulphur is similary purified. It is first melted alongwith Cow Ghee and then poured intp Cow-milk through a filter cloth. Thus the fat solubie impurities are disssolved in the ghee, water(milk) soluble impurities are dissolved in the milk \& the physical impurities are retained by the filter Cloth.

Ghee and milk are Sheeta-Virya media which are known to reduce the toxicity of sulphur to a bodytolerance limit.

\section{3) Urdhvapatana (Sublimation and Distillation)}

The material to be purified is mixed with a paste of acidic medium eg. Lemonjuice and this paste is then applied to an Urdhapatana yantra.

The aromatic substances and the substances having low-vaporization points are treated with Urdhvapatana.

The purified material accumulates on the inner surface of the Upper earthen pot.

eg. Camphor, mercury, letharge $(\mathrm{PbO})$ are purified with this treatment.

\section{4) Adhahpatana (Sublimation and Distillation)}

Treatment is similar like the Urdhvapatana Yantra.

The purified material accumulates in the lower earthen pot

eg. mercury.

Mercury can also be purified by Tiryak patana Yantra.

\section{5) Bharjana (Frying)}

The material to be treated is fried with ghee(eg.Hingu), without ghee(Alum,Borax).

The Hingu is fried so as to remove its moisture content while alum \& borax are fried to evaporate their water of crystallisation. After frying, the material becomes brittles, light and puffed. 


\section{6) Bhavana(Trituration)}

The material to be treated is triturated with other herbs or minerals. The treatment is repeated till the desired therapeutic results are obtained.

The juice/paste of Garlic (eg.Mercury), ginger(eg.Realgar), lemon-juice(eg.Kasisa), Salts(eg.mercury), are generally used for Bhavana Treatment.

The trituration of Herbs and minerals facilitate transfer of soluble impurities from the mineral to herbs, Similarly, the organic components are transferred to the mineral substances.

\section{7) Virecana :-}

The material meant for shodhana treatment is cleansed and sifted.

This remover the aduteration.

Cumin-Seeds, Mustard-seeds, Pippali are purified by this method.

8) Shoshana (Drying)

The material to be purified is shade-dried eg. Seeds of Apamarga, Shigru, Cotton-Seed.

\section{9) Sthapana (Soaking in the liquid medium)}

The material to be purified is soaked into the acidic medium (eg. Cow-urine, Kanji etc.)

The outer shell of Herbal-Poisons eg. Jayapala the outer skin of Vatsanabha are removed with this treatment.

The removal of outer-shell (eg.Jayapala); needle-puncture test(eg.Vatsanabha), the reduction in stickiness (eg.Guggulu) are the few parameters adopted for quality-purification of herbs.

\section{0) Svedana (Boiling or Fomentation)}

The material to be purified is boiled with acidic medium(eg.Shanka, Shukti, Varatika, Prawal, Godanti are boiled with lemon-juice).

The material to be purified is fomented with steam of water or milk.

The external/physical impurities of Shankha, Shukti, Varatika and Prawal are softened which are further removed by cleansing.

The excessive alkalinity of the Shankha, Shukti, Varatika etc. is reduced by boiling with the acidic medium.

The other common treatments applied for shodhana are washing (eg.Bhanga leaves); \& removal of outer Skin (eg. Ginger, Shatavari)

Shodhana Treatment of Loha :-

Rasagranthas have mentioned three types of Loha Viz. Munda, Tikshna and Kanta Loha 8 These types are further subdivided into 3,6 and 5 subtypes respectively.

Impure Loha, on oral administration causes following symptoms in the body ${ }^{6}$.

Hritpida (Chest-Pain)

Agnimandya (Loss of appetite)

Vatavyadhi (diseases due to Vata-dosha)

Rajayakshma

Prameha (Diabetes)

Hrillas (Nausea)

Kushtha (Skin - diseases)

\section{Gulma}

Apasmar (epilepsy)

Shotha (Oedema)

Napunsakata (Impotency)

Ashmari (Renal Calculus)

Mrutyu (Death)

Udarroga

\section{General Shodhana Treatment of Loha :-}

Thin sheets of Loha are heated red hot \& are immersed in sesame oil. After quenching Loha Sheets are reheated and again dipped in another sample of sesame oil. The same sheet is reheated \& quenched into buttermilk, Cow's urine, Sour gruel and decoction of Kulattha respectively, each for seven times.

This treatment helps in fragmentation of Loha, rendering it fragile.

After completion of General Shodhana, a Special Shodhana is performed for Loha.

Special Shodhana Treatment of Loha :-

The coarse powder of Loha (obtained after general shodhana treatment) is heated red-hot and then immersed into a decoction of Triphala with Gomutra. This treatment is repeated for seven times.

\section{Aims of the study :-}

This study is aimed at assessment of physical changes in the Raw Loha after Shodhana Treatment.

\section{Materials and Methods :-}

Thin Sheets of Loha were obtained from Vedashri Ayurved Bhandar, Nashik.

\section{General Shodhana Treatment of Loha :-}


Materials-

Thin Sheets of Loha : $1000 \mathrm{gm}$.

Sesame oil, butter-milk, cow's urine, Sour-gruel; Decoction of Kulattha :- 5 liters each.

Equipments :-

Iron Vessels, Koshthi, Sandhasha, iron-spatula etc.

Method :-

a) General Shodhana Treatment -

Thin Sheets of Loha were heated up to red hot and quenched into sesame oil. This process was repeated for seven times. Similarly, the process was repeated with butter-milk, Cow's urine, sour gruel and a decoction of Kulattha.

b) Special shodhana treatment-

Materials-

Samanya Shodhita Loha Churna : 960 gm.

Equipments-

Decoction of Triphala (Processed with Gomutra) - 5 ltr.

Method-

Iron-ressels, Koshthi, Sandansh, Kadahi, iron-spatula etc.

Samanya shodhita Loha Churna was placed in iron Kadahi. It is then hea for seven times. ted until Loha Churna became red hot and then immediately immersed into a decoction of Triphala. This Process was repeated for seven times.

IV. Observation \& Results :-

General Shodhana Treatment of Loha.

\begin{tabular}{|l|l|l|l|l|}
\hline & Weight & Wr.loss & Colour & Physical Form \\
\hline Raw Loha & $1000 \mathrm{~g}$ & - & Blackish & Thin Sheets \\
\hline In Sesame oil & $990 \mathrm{~g}$ & $10 \mathrm{~g}$ & Dark Brown & Thin Sheets \\
\hline In Butter milk & $985 \mathrm{~g}$ & $5 \mathrm{~g}$ & Dark Brown & Sheets (Cut-pieces) \\
\hline In Cow's urine & $975 \mathrm{~g}$ & $10 \mathrm{~g}$ & Blackish Red & Cut-pieces \\
\hline In Sour gruel & $970 \mathrm{~g}$ & $5 \mathrm{~g}$ & Dark Brown & Small-pieces \\
\hline In Decoction of Kulattha & $960 \mathrm{~g}$ & $10 \mathrm{~g}$ & Dark Brown & Coarse Powder \\
\hline
\end{tabular}

\section{Observation :-}

- The red hot Loha Churna, when immersed into liquids, results into a hissing sound.

Special Shodhana Treatment :-

\begin{tabular}{|c|l|l|l|l|}
\hline & Weight & \multicolumn{1}{|l|}{ Wt. loss } & Colour & Physical Form \\
\hline General shodhita Loha & $960 \mathrm{~g}$ & \multicolumn{1}{|l}{-} & Dark Brown & Coarse Powder \\
\hline Special Shodhana 1 & $956 \mathrm{~g}$ & $4 \mathrm{~g}$ & Dark Brown & Coarse Powder \\
\hline 2 & $954 \mathrm{~g}$ & $2 \mathrm{~g}$ & Blackish & Coarse Powder \\
\hline 3 & $950 \mathrm{~g}$ & $4 \mathrm{~g}$ & Blackish Red & Coarse Powder \\
\hline 4 & $948 \mathrm{~g}$ & $2 \mathrm{~g}$ & Blackish Red & Fine Powder \\
\hline 5 & $946 \mathrm{~g}$ & $2 \mathrm{~g}$ & Dark Brown & Fine Powder \\
\hline 6 & $942 \mathrm{~g}$ & $4 \mathrm{~g}$ & Dark Brown & Fine Powder \\
\hline 7 & $940 \mathrm{~g}$ & $2 \mathrm{~g}$ & Dark Brown & Soft \& Fine Powder \\
\hline
\end{tabular}

\section{Observation :-}

The red hot Loha Churna, when immersed into Triphala Kwatha, results into a hissing Sound.

1. Triphala kwatha turned to greenish Black.

2. A slight color change was observed during special shodhana treatment.

3. Finally a soft \& fine, dark Brown powder of Specially shodhit Loha was obtained.

\section{Discussion}

- The Shodhana treatments for Rasa-dravyas are Nirvapana, Dhalana, Urdhvapatana, Adhahpatana, Bhajana, Bhavana, Virechana, Shoshana \& Svedana

- Impune Loha can cause symptoms like Loss of appetite, Diabetes, Skin-diseases, epilepsy, Impotency, Renal Calculus and even death.

- Hence, Loha should be subjected to a General and Special ShodhanaTreatment.

- Raw Loha, after general treatments led to a physical changes in the different stages. 
- When Loha was purified with sesame oil, a weight loss of $10 \mathrm{~g}$ and colour change (blackish to dark brown) was noticed.

In Butter milk, weight loss was $5 \mathrm{~g}$. with no colour change of Loha.

In Cow's urine, Loha lost $10 \mathrm{~g}$. with a colour change from dark Brown to Blackish Red.

A Weight loss of $5 \mathrm{~g}$. \& $10 \mathrm{~g}$. respectively was observed in the sour gruel and decoction of Kulattha.

The repeated heating and quenching into different media led to the colour changesof Loha. It also resulted into a reduction in hardness of Loha. Hence, thin sheets were converted to a coarse powder of Loha. This could be due to acidic media having different $\mathrm{pH}$.

The specially treated Loha thus lost a weight of $20 \mathrm{~g}$, with an intermediate colour changes. Ultimately, a dark brown, soft $\&$ fine powder was obtained. This may be due to repeated heating \& quenching into Gomutra siddha Triphala Kwatha.

\section{Conclusion:}

The total weight loss of raw Loha during General treatment was 40 g.(1000 g. to $960 \mathrm{~g})$, colour changed from Blackish to Dark Brown; the thin sheets of Loha converted to coarse powder.

The Loha after special shodhana treatment lost 20 g. (960 g. to 940 g.), intermediate colour changes were observed. However, hardness of Loha was remarkably reduced (Coarse powder turned to a soft \& fine powder).

Hence, Loha should necessarily undergo General and Special ShodhanaTreatments which makes it suitable for a further Process of Marana.

\section{Reference:}

[1]. P.V. Sharma, Caraka Samhita (English Translation), Varanasi, Chowkhamba orientalia, $9^{\text {th }}$ edition, 2005; PP. 305

[2]. Dhamanakar P.V., Ayurvediya Aushadhikarana, Panvel, Dhootpapeshwar Prakashan, $1^{\text {st }}$ edition, 1964; PP. 99-102.

[3] P.V. Sharma, Caraka Samhita (English Translation), Varanasi, Chowkhamba Orientalia, $7^{\text {th }}$ ed, 2005; pp. 365.

[4] Rasa Vagbhata, Rasa Ratna Samuchchaya. Shastri Ambika Datta; Chowkhamba Sanskrit Bhavan, $1^{\text {st }}$ ed, 1988; pp.33.

[5] Shree Gopal Krishna Bhatta, Rasendrasarasangraha; Panta Ghanananda, Chowkhamba Sanskrit Series, Varanasi; ${ }^{\text {st }}$ ed; 2005; pp. 3.

[6] Rasa Vagbhata; Rasa Ratna Samuchchaya; Pt. Sharma Shri Dharmananda, Motilal Banarasidas, $2^{\text {nd }}$ ed, 1996; pp.86. 